\title{
Technology of Processing Slags of Copper Production using Local Secondary Technogenic Formations
}

\author{
A.A. Yusupkhodjaev, Sh.T. Khojiev, B.T. Berdiyarov, D.O. Yavkochiva, J.B. Ismailov
}

\begin{abstract}
The article considers the inevitability of copper losses with slag and the possibility of reducing them by various methods and using local secondary technogenic formations. It has been established that the developed and widely used in industry technologies for slag decontamination only partially solve the problem and lead to significant irretrievable losses of metal with dump slag. The main factors affecting the magnitude of the losses are established and suggestions for reducing their negative impact are recommended. The use of perfect mixing devices is recommended, as in this case, it is possible to achieve a maximum reduction in the residual concentration of copper in the waste slag. Together, it is possible to achieve an increase in the complexity of the use of raw materials with the organization and implementation of low-waste technology.
\end{abstract}

Keywords: slag, loss of metals, processing, reduction, sulfidation of oxides, depletion, ideal mixing apparatuses, low-waste technology.

\section{INTRODUCTION}

At present, in the world in the mining and metallurgical industries and, in particular, in Uzbekistan, it has become a necessity to solve a whole complex of complex problems. This is, first of all, all-round depletion of rich and easily discovered ore deposits, increasing requirements for environmental protection, increasing the complexity of the use of raw materials, developing and implementing low-waste technologies.

Despite the wealth of mineral resources, effective forecasting of the development of the economy of Uzbekistan is impossible without taking into account the involvement of mining and metallurgical industries in processing waste, in which the content of valuable components is often significantly higher than in the extracted primary raw materials.

Revised Manuscript Received on November 08, 2019.

* Correspondence Author

Yusupkhodjaev A.A.*, professor of department of "Metallurgy", Tashkent State Technical University, Tashkent, Uzbekistan. Email: hojiyevshohruh@yandex.ru

Khojiev Sh.T., senior teacher and researcher of department of "Metallurgy", Tashkent State Technical University, Tashkent, Uzbekistan. Email: hojiyevshohruh@yandex.ru

Berdiyarov B.T., chairman of department of "Metallurgy", Tashkent State Technical University, Tashkent, Uzbekistan.

Yavkochiva D.O., assistant of Tashkent State Technical University Termez branch, Termez, Uzbekistan.

Ismailov J.B., assistant of department of "Metallurgy", Tashkent State Technical University, Tashkent, Uzbekistan.
The waste and intermediate products of the Almalyk Mining and Metallurgical Combine (AMMC) have accumulated a large number of tailings from concentration plants, copper slag and clinker from zinc cake processing. These materials contain a large number of non-ferrous, noble metals and are actually outside the production cycle. Involving them in processing will allow the plant to significantly expand its raw material base without increasing capital costs for geological and mining operations [1, 2].

So, at present, about 1 billion tons of tailings from enrichment plants with a copper content of $0.07-1.112 \%$ are accumulated in tailings. They contain over 800 thousand tons of copper, 20 thousand tons of molybdenum, 182 friction, 500 thousand tons of zinc and many other valuable components [3].

In the pyrometallurgical method for the production of copper, a large amount of slag is formed with a copper content of $0.60-3.50 \%$. These slags are partially reloaded into melting furnaces, part is stored, and a significant part is processed by flotation. In the best case, copper extraction during flotation is $40-60 \%$, the rest of the copper, and also gold and silver, are irretrievably lost with slag tails.

The zinc production clinker contains over $2.2 \%$ copper, $2.40 \%$ zinc, $0.01 \%$ cadmium, $5-8 \mathrm{~g} / \mathrm{t}$ gold, $250-500 \mathrm{~g} / \mathrm{t}$ silver and many other valuable components. Some of the clinker is loaded into melting furnaces, and a significant part is stored in slag storage.

The involvement of these materials in production will allow the plant to additionally obtain thousands of tons of copper, a significant amount of precious metals and other valuable products.

Tailings ponds and, especially, slag dumps attack the natural territory, occupy thousands of hectares of farmland, pollute the air basin and disfigure the landscape. Assessment of damage from environmental pollution leads to a significant expansion of the boundaries of economic feasibility of creating and applying low-waste technology. Given this circumstance, of course, the economic efficiency of combining production increases and new criteria arise for the formation of production structures in industry related to environmental impact [4].

In this regard, the task of creating a rational and integrated technology for the processing of slag and secondary industrial formations of local industrial enterprises is very important. 


\section{OBJECTS AND METHODS OF RESEARCH}

When performing this work, most of the well-known, widespread, accessible methods and facilities were used [5, 6]. Some methods developed by the authors during the implementation of these studies [7].

Chemical and microscopic methods were used to determine the material composition of solid slag and other materials. Microscopic analysis of quenched and crystallized slag allows one to estimate the distribution of copper in terms of components and extrapolate these results to the forms of the presence of copper in the melt. Additional opportunities in this direction are associated with the use of electronic microprobe analysis, which allows determining the selective composition of structural components by conducting a point analysis. For a deeper determination of the structural characteristics of the slag, diffraction and spectroscopic methods were used. An important characteristic of the slag is the value of $\mathrm{P}_{\mathrm{O} 2}$ and $\mathrm{P}_{\mathrm{S} 2}$, which were determined by circulating and static methods.

To study the processes occurring in a layer of charge materials during its heating, we determined the change in the electrical resistance of the material formed in the manufacturing process from the starting components. The electrical resistance was measured using a voltmeter-ammeter circuit, making it possible to measure the circuit resistance continuously and with great accuracy. The circuit was powered from an alternating current network through a generator, which made it possible to regulate the output voltage from $100 \mu \mathrm{V}$ to $30 \mathrm{~V}$, and the frequency in the range from $20 \mathrm{~Hz}$ to $10 \mathrm{MHz}$. The range of measured voltages ranged from $10 \mu \mathrm{V}$ to $1 \mathrm{~V}$. If it was necessary to set the voltage in the circuit above 1 , the millivoltmeter was turned off and the output voltage was set by the millivoltmeter mounted in the generator. The indicators of the depletion process and its kinetics are largely determined by the melting temperature of the charge materials in the furnace. The melting temperature of the starting components, taken in various ratios, was determined using a micro-furnace, the general view and diagram of which are presented in [8]. The micro-furnace was calibrated using pure salts with a constant melting point. The following were used as reference mixtures: $\mathrm{ZnCl}_{2}\left(313{ }^{\circ} \mathrm{C}\right), \mathrm{CdCl}_{2}\left(568{ }^{\circ} \mathrm{C}\right), \mathrm{CaCl}_{2}\left(772{ }^{\circ} \mathrm{C}\right), \mathrm{NaCl}(800$ $\left.{ }^{\circ} \mathrm{C}\right), \mathrm{NaF}\left(995{ }^{\circ} \mathrm{C}\right), \mathrm{Na}_{2} \mathrm{SiO}_{3}\left(1088{ }^{\circ} \mathrm{C}\right), \mathrm{CaSO}_{4}\left(1450{ }^{\circ} \mathrm{C}\right)$, $\mathrm{BaSO}_{4}\left(1580{ }^{\circ} \mathrm{C}\right)$.

When heated, the charge materials become liquid. The formation of the final melting products - matte and slag, the degree of their separation, and, ultimately, the result of depletion, is greatly affected by the viscosity of the melts formed. Viscosity was determined by the method of damped oscillations, the technique of which the text is described in the literature.

To create a neutral atmosphere, a refractory tube was introduced into the furnace through which $21 / \mathrm{min}$ of argon was blown.

The charge was melted and the viscosity changed in a molybdenum crucible. A spindle made of molybdenum was lowered into the melt. The temperature was controlled by a tungsten - rhenium thermocouple. The experiments were carried out in the temperature range $1200-1600{ }^{\circ} \mathrm{C}$.

In order to conduct basic research and elucidate the basic laws of physicochemical transformations taking place in a lean furnace, pure materials were used (analytical grade): hematite $\mathrm{Fe}_{2} \mathrm{O}_{3}$, calcium oxide $\mathrm{CaO}$, silicon dioxide $\mathrm{SiO}_{2}$. Technological magnetite obtained from mineral raw materials (up to $99 \% \mathrm{Fe}_{2} \mathrm{O}_{3}$ ). In order to achieve better purity of magnetite, the raw material after fine grinding was subjected to repeated magnetic cleaning by passing it through a magnetic separator with a weak magnetic field, 150 Oersted $(\mathrm{g} / \mathrm{m})$.

Technological parameters were determined using materials that are intermediate products and waste from local industrial enterprises. The selection of these materials was carried out taking into account the problems solved by the authors on the reduction of magnetite, sulfidation of oxidized copper compounds, bubbling a liquid bath, creating a weakly reducing atmosphere in the furnace, and obtaining slag of an optimal composition and properties. When selecting materials, the authors were guided by the main provisions of the concept of depletion developed by them, the main provisions of which are:

1) The technology should be based on the use of only local materials, which are intermediate products and production wastes;

2) The technology should not require additional capital investments;

3) The technology should not exceed the emission of harmful gases beyond the limits of permissible norms;

4) The technology should ensure a reduction in the amount of processing;

5) The technology should be able to extract additional production of associated materials, such as gold and silver.

The selection of components was carried out in such a way as to purposefully change and control the composition of the slag, in which the loss of copper and other valuable components would be minimal.

Of the many sources of raw materials, preference was given to those materials, which included copper, precious metals and other valuable elements. This made it possible not only to solve the main problem of extracting copper from slag, but also to additionally obtain valuable metals.

The main object of research was the slags of the smelter production of the Almalyk Mining and Metallurgical Combine (AMMC). The composition of the main components of the slag are presented in table 1.

The authors subjected the chemical analysis to both the stale accumulated and the current slags that formed. Noteworthy is the wide variation in the composition of the slag, especially in the copper content in them. In Oxygen-flare Smelting (OFS) slags, the copper content ranges from 0.73 to $1.33 \%$, in Converter slags from 1.60 to $3.56 \%$, Reverberatory smelting redistribution (RS) $0.52-0.72 \%$, Vanyukov's process or Smelting in a liquid bath (SLB) $0.70-1.10 \%$. Such a wide variation in slag compositions is explained by the specific conditions of metallurgical smelting and the variety of incoming raw materials. The presented figures are the average of several parallel analyzes and therefore are fairly reliable. Considering the need for a large volume, in this case, the authors chose converter slags as the object of research, with the largest proportion of copper content in them ranging from $2.30-3.30 \%$.

The authors chose a zinc clinker from the Almalyk Mining and Metallurgical Combine (in Uzbekistan) as a reducing agent. 
This choice is due to both the content of valuable components in it and its high chemical activity [9, 10]. The composition of clinker for the main components is given in table 2 .

The authors selected zinc tails from the lead dressing plant of the Almalyk mining and metallurgical combine as a sulfidizing agent. The choice was determined by the existing large reserves, the lack of demand at the mill and the rather high sulfur and copper contents in them. Moreover, the copper content is comparable with the copper-molybdenum ores of the Kalmakir deposit of AMMC (0.37 - 0.42\% Cu). The chemical composition of the main components of zinc tails is given in table 3 .

In the course of the experiments, liquid converter slag was used. The charge for the lean furnace was selected based on the production of slags with a content of $34-36 \%$ silicon dioxide, $0.35-0.40 \%$ copper and matte with a content of $18-25 \%$ copper with minimal desulfurization. The temperature of matte and slag was maintained at $1100-1200$ and $1200-1300{ }^{\circ} \mathrm{C}$, respectively.

\section{THE RESULTS AND DISCUSSION}

The use of secondary technogenic formations of local industrial enterprises can be carried out when developing an effective technology for processing slag from copper production. When selecting these materials, it is necessary to take into account the complex on manufacturability, accessibility of materials, environmental protection, economic efficiency and competitiveness. The creation of such a technology requires a detailed study of the theory of the process, physico-chemical transformations of the components of the mixture in liquid and solid states in various gas atmospheres.

Numerous parameters affect the copper content in slags, of which the following should be considered as the most important [11]: preparation of the charge, parameters of the technological mode of smelting, physicochemical properties of the melts, design of units, organization of work, and so on. It is very difficult and hardly possible to give an exhaustive assessment of the influence of all parameters acting individually or in combination. In this regard, we will try to evaluate individual process parameters from the angle of their influence on depletion indices and the possibility of changing their values in real metallurgical smelting.

The preparation of the mixture plays a very important role for any metallurgical processes. It would be ideal to use a bedding system for this purpose $[12,13]$. However, this will require large capital expenditures for the construction of the charge preparation machine, significant free areas, and stocks of raw materials are necessary, which is difficult to implement in the conditions of the existing Almalyk mining and metallurgical combine.

In addition, for production needs, it is planned to process with accumulated materials and waste from various industries, the special preparation of which will negatively affect the economic performance of the process. For these reasons, special expensive preparation of the charge is not planned.

The manufacturability and feasibility of the developed technology will be closely related to the unit, which is taken as the basis. According to the long-term plan for the modernization and reconstruction of the Almalyk smelter, a second melting furnace in a liquid bath is planned to be decommissioned. It is this furnace that is recommended for the lean process. There are no other possibilities for using such equipment at the AMMC. To increase the efficiency of the reflective redistribution, the authors developed recommendations for a significant increase in the calorific value of the mixture with an increase in the mass of slag, and without this process. This will simultaneously increase the sulfur dioxide content in process gases up to $6-9 \%$, which will allow them to be used to produce sulfuric acid. The increase in the calorific value of the charge will almost halve the consumption of hydrocarbon fuel for heating the furnace.

The organization of work makes a certain contribution to the efficiency of the depletion process. However, there are practically no opportunities for a significant change in the systems used for organizing production, and, apparently, this is not necessary.

From the above it follows that the real lever for controlling the quality of the lean process is the selection of the optimal technological mode of smelting and, closely related to it, the physicochemical properties of slag and matte melts.

The technological mode of smelting primarily means: optimal compositions of slag and matte, oxidation potential of the gas phase, temperature, as well as the physicochemical properties of the melts, which are closely related to each other [14].

All of the above process parameters have a significant effect on the content of copper in the slag. However, far from all of them can vary in broad representations, providing the opportunity to influence the final results of depletion. For example, the upper temperature limit is limited by the resistance of refractories in an aggressive environment and the increased solubility of copper under these conditions. The lower limit is limited by the fluidity of the melts, the difficulty of separating the slag and matte due to a sharp increase in viscosity with decreasing temperature and so on. Therefore, under real conditions of copper pyrometallurgy, the temperature of the melts can vary between 1250 and $1300^{\circ} \mathrm{C}$, i.e. this factor cannot be used to effectively control the copper content in slag [15]

The composition of the gas phase is a very important factor affecting the content of copper in slag. It is considered ideal to work in neutral and reducing atmospheres, although the amount of oxygen supplied to the furnace for the combustion of hydrocarbon fuels can be easily adjusted to create the desired atmosphere, but in real production conditions it is almost impossible to do. The fact is that melting furnaces are far from perfect in terms of preventing harmful suction of secondary air. For this reason, the gas atmosphere of the furnace above the melt will be mainly oxidizing and special measures must be taken to reduce its harmful effect [16].

The composition of the matte directly affects the copper content in the slag. However, there are no opportunities for its wide variation. The fact is that when working on rich mattes, the copper content in the slag increases. Upon receipt of a unit of production, work on poor matte increases its volume and causes large copper losses during the subsequent conversion operation. As a result, metallurgists are forced to work with matte containing 30 - $46 \%$ copper [17]

Thus, one of the real effective levers in controlling the quality of the depletion process is the selection of an effective slag 
composition with optimal physicochemical properties [18].

A study of the literature on the processing of copper slag, analysis of practical work, as well as the results of their own research and development, allowed the authors to establish that the success of the depletion process is largely determined by the solution of the following problems [19 - 20]:

- reduction of magnetite slag to $\mathrm{FeO}$;

- adjustment of the slag composition and work on the optimal content of such components as $\mathrm{SiO}_{2}, \mathrm{CaO}, \mathrm{FeO}$, $\mathrm{Fe}_{3} \mathrm{O}_{4}$ and others;

- sulfidation of oxidized copper compounds and their transfer to the matte phase;

- bubbling the melt with gases in order to create conditions for the coalescence of small drops of matte;

- transferring small drops of matte into the bottom phase by mixing with matte;

- binding of sulfur to the condensed phase, which allows us to simultaneously reduce the desulfurization to an acceptable limit and transfer it to matte.

The complex of the above measures will reduce the solubility of copper sulfide in slag and extract the dissolved copper into matte, convert oxide copper to sulfide form, and conditions will be created for the precipitation of the fine suspension of sulfides formed in the bottom phase.

Each of the above factors has its own specific features and opportunities for implementation in terms of the impact on the final results of the lean process.

The need to restore magnetite is due to the following circumstances. The oxidizing atmosphere of the furnace creates good conditions for the transition of wustite $(\mathrm{FeO})$ to magnetite $\left(\mathrm{Fe}_{3} \mathrm{O}_{4}\right)$. At concentrations exceeding the solubility limit of $\mathrm{Fe}_{3} \mathrm{O}_{4}$ in the slag, magnetite goes into matte and creates great difficulties in its further processing. Within the limits of its solubility in slag $(10-20 \%)$, magnetite significantly changes such melt properties as density and viscosity. The increase in density complicates the separation of slag and matte, and this, in turn, leads to a significant increase in copper losses with slag. An increase in slag viscosity reduces its fluidity, creates great difficulties in removing the melt from the furnace, and significantly increases the amount of entangled metal particles. This implies the need for the maximum possible reduction of magnetite in the furnace [27].

Magnetite under metallurgical conditions can be restored as a result of the following reactions [28]:

$$
\begin{array}{r}
\mathrm{Fe}_{3} \mathrm{O}_{4}+\mathrm{Fe}=4 \mathrm{FeO} \\
\mathrm{Fe}_{3} \mathrm{O}_{4}+\mathrm{C}=3 \mathrm{FeO}+\mathrm{CO}
\end{array}
$$

$3 \mathrm{Fe}_{3} \mathrm{O}_{4}+\mathrm{FeS}+5 \mathrm{SiO}_{2}=5\left(2 \mathrm{FeO} \cdot \mathrm{SiO}_{2}\right)+\mathrm{SO}_{2}$

The presence of free silicon dioxide in the melt reduces the activity of wustite and contributes to a more complete restoration of magnetite as a result of the fayalite $\left(2 \mathrm{FeO} \cdot \mathrm{SiO}_{2}\right.$ or $\mathrm{Fe}_{2} \mathrm{SiO}_{4}$ ) formation reaction:

$$
2 \mathrm{FeO}+\mathrm{SiO}_{2}=\mathrm{Fe}_{2} \mathrm{SiO}_{4}
$$

From the point of view of environmental protection, it is more expedient to restore magnetite by reactions (1) and (2), since the development of reaction (3) leads to the emission of free sulfur dioxide into the air.

Under the conditions of the Almalyk MMC, for the implementation of reactions (1) and (2), zinc clinker, which contains carbon and metallic iron, can be used. In addition to clinker, various carbon-containing materials (coke, coal), gaseous and liquid fuels, and also non-ferrous metals with a higher affinity for oxygen (for example, aluminum waste) can be used as a reducing agent. However, the use of clinker is advisable, because in addition to reducing agents, it contains a noticeable amount of non-ferrous and precious metals, which will also be extracted into the finished product and will significantly, reduce the cost of redistribution. For these reasons, in our studies, clinker was chosen as the main reducing agent.

A successful copper extraction process is only possible under operating conditions with an optimal slag composition.

An analysis of factory practice data revealed that the content of $\mathrm{FeO}, \mathrm{SiO}_{2}, \mathrm{CaO}, \mathrm{Fe}_{3} \mathrm{O}_{4}$ in them directly affects the stability of the slag composition.

Other oxides that make up the slag $\left(\mathrm{ZnO}, \mathrm{Al}_{2} \mathrm{O}_{3}, \mathrm{BaO}\right.$, etc.) are not introduced into the mixture as fluxes, but are contained in small quantities in the starting components. Therefore, evaluating their influence on the loss of metals with slag, it is difficult to count on the possibility of active influence of these components on the course of the metallurgical process [29]. A study of the available literature allowed us to establish that the minimum copper losses are achieved when slags of the following composition are obtained: $41-46 \% \mathrm{SiO}_{2}, 11-15 \% \mathrm{CaO}, 21-26 \% \mathrm{FeO}$. It is to work with such a slag composition that the selection of starting materials for the depletion process will be directed.

To regulate the composition of the slag, limestone, tailings of lead and copper concentrating plants of AMMC will be used. In these materials, along with the components regulating the composition of the slag, there is a noticeable amount of non-ferrous metals, the additional extraction of which will favorably affect the technical and economic indicators of the entire depletion process. So, in the tailings of the lead concentration plant of AMMC contain: $\mathrm{Cu} 0.10-0.25 \%$; Mo $0.025-0.030 \%$; Au $0.40-0.50 \mathrm{~g} / \mathrm{t} ; \mathrm{Ag} 1.4-2.6 \mathrm{~g} / \mathrm{t}$ and others [30, 31].

An indispensable condition for slag depletion is its recovery in order to reduce substances with $\mathrm{Fe}^{3+}$ (ferric ions) dissolved in them.

Restore toxins in the most rational way by blowing dust. Obviously, it is most convenient to use natural gas. However, the utilization rate of unconverted gas is very low. The reduction can be carried out in a fixed bed, for which a solid reducing agent is loaded onto the surface of the melt. Probably, due to the low speed of the processes of mass transfer, recovery will proceed slowly. Therefore, an assumption should be given to processes combining reduction with melt mixing.

Due to the oxygen dissolved in the melt, as well as the high oxidizing potential of the gas phase, up to $10 \%$ of the copper in the slag is in the oxidized state. If you do not take special measures for their sulfidation, they will be almost completely lost with slag. As sulfidizers, we used zinc tails of the lead concentration plant of the AMMC and phosphogypsum of the Almalyk chemical plant (in Uzbekistan).

Based on the consideration of some theoretical issues, the main directions of laboratory research on the depletion of copper-containing slag by reduction with sulfidizing compositions were determined.

In the first series of experiments, the authors investigated the possibility of decontaminating converter slag with clinker additives. Trial experiments showed that clinker consumption in an amount of $10-30 \%$ reduces the copper content in the slag 
from $2.95-3.50$ to $0.4-0.55 \%$. The content of magnetite in the slag decreases from 20.05 to $30.04-5.25 \%$. Given these results, as well as based on technical and economic calculations, in real-world research conditions, clinker additions to the initial converter slag were 5-25\% [32].

The results of laboratory tests are presented in Fig. 1.

When 10 to $25 \%$ of clinker is added, three liquid phases are formed as a result of melting: slag, matte and metal alloy. It was assumed that an increase in clinker consumption should increase the degree of extraction of not only copper, but also iron from the slag. In this case, the composition of the slag should change in the direction of increasing the content of silicon dioxide. Chemical analysis data showed that with the addition of $5 \%$ clinker, the iron content in the slag decreased by about $2 \%$ and then remained constant. Unusual is a decrease in the concentration of silica in the slag by almost $4 \%$. In addition, a very high (55-70\%) content of copper in matte. These results are presented in Fig. 2.

The results obtained during slag melting together with clinker at $1573 \mathrm{~K}\left(1300{ }^{\circ} \mathrm{C}\right)$ may not be effective due to the interaction of iron with clinker carbon with slag due to contact and a low reaction rate under these conditions. It is important to find out, since under industrial conditions in the smelter, the clinker will directly melt together with the slag.

Slag was melted with the addition of $20 \%$ clinker at various agitation times with argon (from 10 to 40 minutes). The results of these experiments are presented in Fig. 3.

The research results showed that in the case of intensive mixing, the reducing effect of clinker on slag somewhat increases. This reduces the content of copper and zinc in the waste slag to 0.57 and $0.02 \%$, respectively.

Smelting products are only two phases - slag and a sulfide-metal alloy containing $5-10 \%$ sulfur and $12-17 \%$ copper.

As the mixing time increases, the contents of copper and iron in the slag decrease from 1.60 to 0.6 and from 47 to $32 \%$, respectively, and the concentration of silica increases from 20 to $30 \%$. The results showed the principal possibility of interaction between converter slag and clinker, but this process requires an increase in temperature $\left(1300{ }^{\circ} \mathrm{C}\right)$. In addition, intensification can be achieved by mixing the melt and the mixture, the introduction of additional materials.

An increase in temperature above the established parameters, and intensive mixing of a melting furnace under real conditions is difficult to implement, while the most affordable is the introduction of additional materials, which are taken as the basis in these studies.

It was previously established that when only clinker is added to the slag, the slag yield decreases from 88 to $81 \%$. This indicates that part of the oxides from the slag is reduced by clinker, and the degree of utilization of metallic iron and carbon during the process of decontamination is reduced. Kinetic difficulties lead to the fact that the metal-sulfide alloy quickly transitions to the liquid state and leaves the zone of interaction with slag and matte, forming the bottom phase. As a result, mainly in the charge, sulfur also goes into matte.

The intensification of the process of interaction of the slag with matte can be achieved by joint mixing with the extracting phase to study these processes, taking into account the application to real conditions of AMMC, special studies were carried out.
Argon was used as the mixing phase. The results of the study are presented in Fig. 3. Analysis of the results presented in Fig. 3 shows that the extraction of copper into matte increases with increasing mixing time from 69.8 to $77.5 \%$. However, the residual copper content in lean slag remains rather high $(0.57-0.98 \%)$. Despite the fact that the slag yield is not high (10.0 - 10.7\%), nevertheless, copper losses will be significant and this mode is hardly advisable to recommend for industrial implementation.

Comparison of the data presented in Fig. 2 and 3 show a decrease in the matte copper content. This can be explained by a decrease in the duration of the process of decontamination, a reduction in the consumption of reducing agent and the particular conditions of the technological process.

To implement the depletion process, it is advisable to study the effect of mixing with argon under the conditions of using not only clinker, but also other components of the reduction-sulfiding complexes (RSC).

The results of laboratory studies on the dehydration of converter slag with the loading of clinker from the Almalyk zinc plant (in Uzbekistan), gypsum from the neutralization of the sulfuric acid shop of the smelter with the addition of limestone and tails of the copper processing plant under conditions of melt mixing with argon are presented in Fig. 4.

From the data in Fig. 4 shows that when depleted under these conditions, a sufficiently high recovery of copper in matte is achieved. However, matte turns out to be depleted (18.0 - 20.50\%).

Experimental conditions: 30 g slag sample, settling time 30 min, copper content in the initial slag $2.30 \%$.

The residual copper content in the slag is quite low and it is close to the theoretically and technologically feasible recovery of copper from the slag. Fig. 4 shows that the concentration of copper in the slag with stirring for 30 minutes is $0.33-0.37 \%$. These slags may well be dumped and sent to the production of building materials. The conditions of these experiments could be recommended for industrial implementation. However, mixing with argon under real conditions of a melting furnace is a difficult task; in addition, under these conditions, a rather high desulfurization is observed, which may entail the emission of sulfur-containing gases into the air basin beyond the established norms [33].

In Fig. 1 shows the dependence of the extraction of copper into matte and the yield of this matte as a function of clinker consumption. The graph shows that an increase in clinker consumption leads to a decrease in the yield of rich matte. This can be explained by the fact that large clinker additives lead to the formation of an independent strongly metallized phase. They contain $70-75 \%$ iron, 7 - 15\% copper and 5 - $8 \%$ sulfur. From the information of the same plant, it can be seen that an increase in clinker consumption leads to some increase in the extraction of copper into matte. From this point of view, the addition of an additional amount of clinker fully affects the results of decontamination.

Given the above, in this case, three phases are actually formed, which require an independent processing technology. It is unlikely that such a technology has prospects and hence it is necessary to conclude that the high cost of the clinker is not always advisable. 
In Fig. 2 shows the dependence of the copper content in matte on clinker consumption. It can be seen from the figure that an increase in clinker consumption leads to a decrease in the copper content in matte. This can be explained by an increase in the proportion of metallic iron in the matte $\mathrm{Cu}-\mathrm{Fe}-\mathrm{S}$, which forms the basis of copper mattes. Comparison of the research results presented in Fig. 1 and 2 indicates the need to determine clinker consumption taking into account the matte yield, the copper content in it and its extraction from converter slag. In this case, it should be assumed that under real conditions of a melting furnace, mixing with argon is unlikely to be applied.

From the above studies, we can conclude that one recovery process is not enough for the efficient separation of copper from slag. It is also necessary to carry out sulfidation of oxidized copper compounds and its transfer to the matte phase.

To this end, the authors conducted a study in the converter slag-clinker-limestone-FeS $\mathrm{S}_{2}$ (tailings of a lead enriching factory) $-\mathrm{SiO}_{2}$ (tails of a copper enriching factory) system.

A study of the effect of sulfidizers on the efficiency of depletion of converter slag by clinker was carried out by adding pyrite-containing tailings of a Lead Enriching Factory (LEF) to the charge. At the same time, the slag composition was adjusted by adding limestone and tails of a Copper Enriching Factory (CEF) containing quartz. LEF tails contain $50-55 \%$ pyrite [34].

There are works [34-37] devoted to the study of the process of sulphidation of slag by pyrite, while some researchers used pyrite concentrate with a pyrite content of up to $100 \%$. It was noted that the residual copper content in the pyrite slag decreases with the addition of pyrite more than $10 \%$ by weight of the slag.

In our studies, the authors conducted a number of depletion swimming trunks at a temperature of $1300{ }^{\circ} \mathrm{C}$. The amount of reducing agent (clinker), sulfizer (tailings of LEF) and fluxing additives was changed. When calculating additives based on the need to change the composition of matte and slag in a wide range. The research results are presented in Fig. 5 - 8. In Fig. 5 shows the relationship between the amount of sulfidizer introduced and the amount of matte produced.

It can be seen from the data that the matte yield is directly proportional to the amount of sulfidizer over the entire change interval. It can be seen that the same amount of sulfidizer with an increase in clinker additives gives an increase in the yield of matte. This indicates that the formation of matte is carried out mainly due to pyrite in the tailings of LEF and metallic iron clinker.

To clarify this dependence, the interaction results are presented in coordinates: matte weight in grams - pyrite amount in grams, with different clinker additives (\% of slag weight) Fig. 6.

As can be seen from Fig. 5, the considered relationship for a series of experiments with the same amount of clinker turned out to be linear. It was found that the addition of one gram of pyrite leads to an increase in the amount of matte with $5 \%$ clinker by 1.3 grams, and with $20 \%$ clinker - 1.2 grams. Comparison of stoichiometric ratios between $\mathrm{FeS}_{2}$ and $\mathrm{Cu}_{2} \mathrm{~S}$ shows that excess pyrite sulfur in the amount of 0.27 grams per 1 gram of pyrite, in the case of copper sulfidation, gives an increase in matte weight by 1 gram, and in the case of iron sulfidation - by 0.45 grams. This gives reason to believe that, mainly, the sulfidizer is consumed for sulfidation of iron. In addition, the authors compared the increase in matte weight by 2.6 and 2.4 grams (with a constant amount of sulfidizing agent - 5.12 grams), an increase in clinker additives from 10 to $20 \%$ (which corresponds to the introduction of 1.7 grams of metallic iron), the following can be noted:

- with an increase in the amount of clinker, the matte weight increases not only due to the transition to matte, but also by an increase in copper recovery, which may be associated with a decrease in desulfurization.

If we take into account the fact that all depletion melts were carried out under reducing conditions and the magnetite content in the slag was within $2-5 \%$, then we can tentatively calculate (by the sulfur, copper and iron content) of the melt the metallization degree of matte, neglecting the oxygen content in it . In a comparative analysis of relative values, this error will play an even smaller value.

Fig. 7 shows the conditions of the degree of metallization depending on the ratio of reducing agent to sulfidizing agent in the reducing - sulfidizing complexes.

Analyzing the infogram in Fig. 7, you can see that the data are quite close to a certain line, regardless of what level of the additive $(5,10,15 \%)$ the given ratio is carried out, which indicates the formation of matte mainly due to the sulfidizer and reducing agent and the second, this a certain slowdown in the increase in metallization with increasing sulfidization-reducing agent ratio, which is probably associated with an increase in the degree of metallization, with an increase in the proportion of metallic iron in the reduction of magnetite with binding sulfur in sulfide iron.

Useful information for predicting the matte composition during lean melting with pyrite content of cake gives a graphical representation of the dependence of the copper content in matte on the amounts of added sulfidizing agent (Fig. 8). The results presented in Fig. 8 confirms the significance of both the amount of sulfidizing agent and the reducing agent in the matte composition formed and it is possible to accurately predict the quality of the resulting extracting phase.

Table 1: The chemical composition of the slag AMMC

\begin{tabular}{|c|c|c|c|c|c|c|c|c|c|c|c|}
\hline \multirow{2}{*}{ № } & \multirow{2}{*}{ Slag type } & \multicolumn{10}{|c|}{ Content, \% } \\
\hline & & $\mathbf{C u}$ & $\mathbf{F e}$ & $\mathrm{SiO}_{2}$ & $\mathbf{A l}_{2} \mathbf{O}_{3}$ & $\mathrm{CaO}$ & $\mathbf{Z n}$ & $\mathbf{P b}$ & $\mathrm{Fe}_{3} \mathrm{O}_{4}$ & $\mathbf{S}$ & MgO \\
\hline \multirow{3}{*}{1} & \multirow{3}{*}{ OFS } & 0,73 & 31,6 & 32,6 & 6,90 & 0,70 & - & - & 16,1 & 2,10 & - \\
\hline & & 0,98 & 34,2 & 30,9 & 7,30 & 1,40 & - & - & 18,6 & - & - \\
\hline & & 1,33 & 42,9 & 24,8 & 6,30 & 1,70 & - & - & 21,1 & - & - \\
\hline \multirow{3}{*}{2} & \multirow{3}{*}{ Conv. } & 1,60 & 44,2 & 26,0 & 1,70 & 1,60 & - & - & 16,5 & - & - \\
\hline & & 2,51 & 48,8 & 22,4 & 1,80 & 1,44 & - & - & 19,1 & - & - \\
\hline & & 3,56 & 46,5 & 19,0 & 3,26 & 1,57 & - & 0,52 & 19,7 & & \\
\hline
\end{tabular}


International Journal of Innovative Technology and Exploring Engineering (IJITEE)

ISSN: 2278-3075, Volume-9 Issue-1, November 2019

\begin{tabular}{|c|c|c|c|c|c|c|c|c|c|c|c|}
\hline \multirow{3}{*}{3} & \multirow{3}{*}{$\mathbf{R S}$} & 0,52 & 44,6 & 36,4 & 6,30 & 3,10 & - & - & - & 2,10 & - \\
\hline & & 0,61 & 44,6 & 31,0 & 3,80 & 4,60 & - & - & 1,20 & 2,40 & - \\
\hline & & 0,72 & 48,5 & 30,1 & 4,10 & 2,90 & - & - & - & 2,70 & 1,30 \\
\hline \multirow{3}{*}{4} & \multirow{3}{*}{ SLB } & 0,73 & 35,2 & 30,1 & 4,99 & 2,66 & 1,70 & 0,46 & - & 0,70 & - \\
\hline & & 0,80 & 35,1 & 29,9 & 4,88 & 2,76 & 1,60 & 0,52 & - & 0,60 & - \\
\hline & & 1,10 & 36,1 & 28,8 & 5,08 & 2,66 & 1,50 & 0,62 & - & 0,45 & - \\
\hline
\end{tabular}

Table 2: The chemical composition of the clinker AMMC

\begin{tabular}{|c|c|c|c|c|c|c|c|c|c|c|c|c|}
\hline \multirow{2}{*}{ № } & \multirow{2}{*}{$\begin{array}{l}\text { Type of } \\
\text { clinker }\end{array}$} & \multicolumn{11}{|c|}{ Content, \% } \\
\hline & & $\mathbf{C u}$ & Zn & $\mathbf{P b}$ & $\mathbf{F e}$ & Cd & In & $\mathrm{SiO}_{2}$ & As & Au & Ag & $\mathrm{C}$ \\
\hline 1 & KL-2 & 2,24 & 2,35 & 0,50 & 30,0 & 0,01 & 0,001 & 15,6 & 0,30 & $\begin{array}{c}5-8 \\
\mathrm{~g} / \mathrm{t}\end{array}$ & $\begin{array}{c}300- \\
500 \mathrm{~g} / \mathrm{t}\end{array}$ & 12,0 \\
\hline 2 & KL-3 & 2,21 & 2,69 & 0,60 & 34,0 & 0,01 & 0,009 & 18,0 & 0,30 & $\begin{array}{c}2-5 \\
\mathrm{~g} / \mathrm{t}\end{array}$ & $\begin{array}{c}250- \\
300 \mathrm{~g} / \mathrm{t}\end{array}$ & 12,5 \\
\hline
\end{tabular}

Table 3: The chemical composition of the zinc tails of the lead beneficiation plant AMMC

\begin{tabular}{|c|c|c|c|c|c|}
\hline № sample & Composition & Content, \% & $\begin{array}{c}\text { № } \\
\text { sample } \\
\end{array}$ & Composition & Content, \% \\
\hline 1 & $\mathbf{P b}$ & 1,02 & 10 & Sb & 0,0002 \\
\hline 2 & $\mathbf{Z n}$ & 1,65 & 11 & Te & 0,0075 \\
\hline 3 & $\mathrm{Cu}$ & 0,30 & 12 & In & 0,0003 \\
\hline 4 & $\mathbf{F e}$ & 27,5 & 13 & $\mathbf{A l}_{2} \mathbf{O}_{3}$ & 4,25 \\
\hline 5 & Cd & 0,02 & 14 & Co & 0,0075 \\
\hline 6 & $\mathbf{B i}$ & 0,0033 & 15 & MgO & 6,11 \\
\hline 7 & $\mathbf{S}$ & 21,4 & 16 & Se & 0,0018 \\
\hline 8 & $\mathrm{SiO}_{2}$ & 29,4 & 17 & Mn & 0,50 \\
\hline 9 & As & 0,028 & 18 & $\mathrm{CaO}$ & 7,61 \\
\hline
\end{tabular}

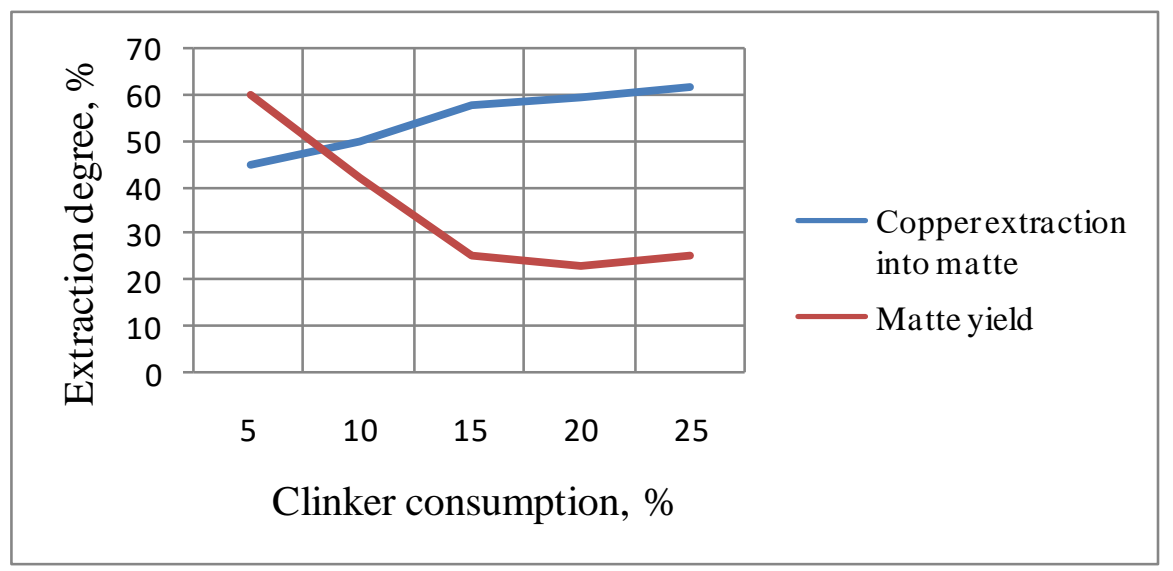

Fig. 1. Dependence of copper extraction into matte and matte yield on clinker consumption of Almalyk Zinc Plant (\% of the weight of the initial slag)

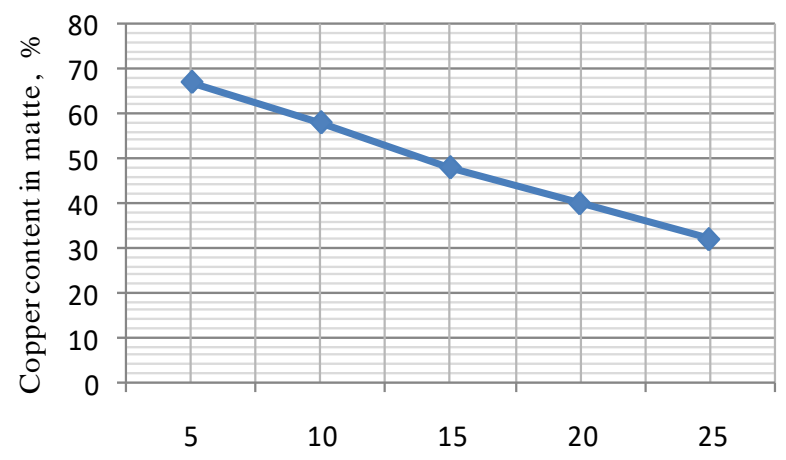

Clinker consumption, $\%$

Fig. 2. The dependence of the copper content in matte on clinker consumption (\% of the weight of the original slag) 


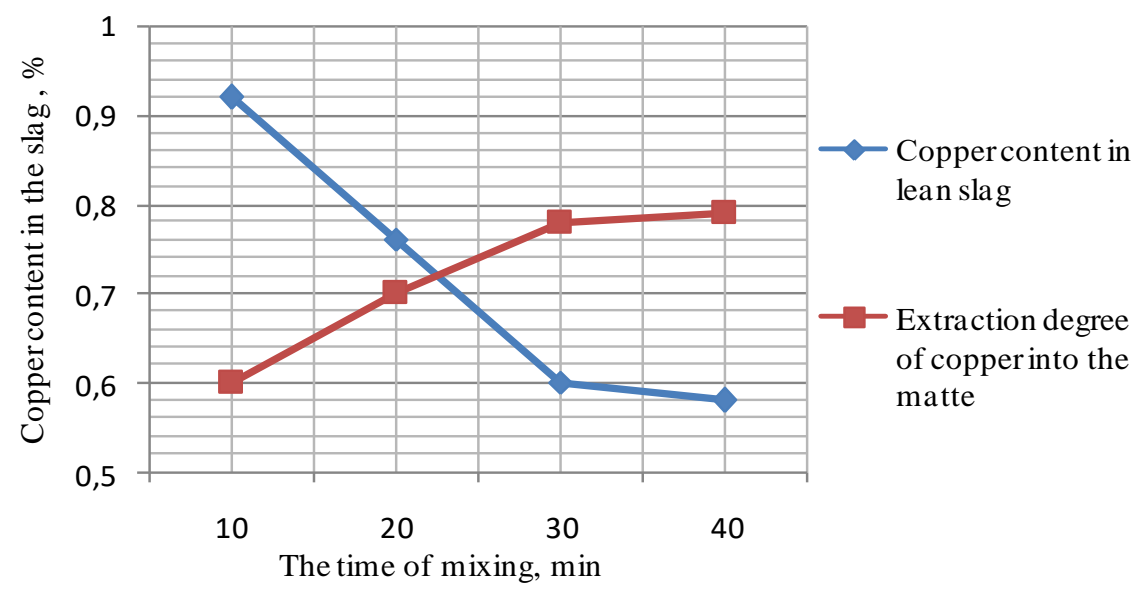

Fig. 3. The dependence of the residual copper content in the slag and its extraction in matte on the time of mixing with argon

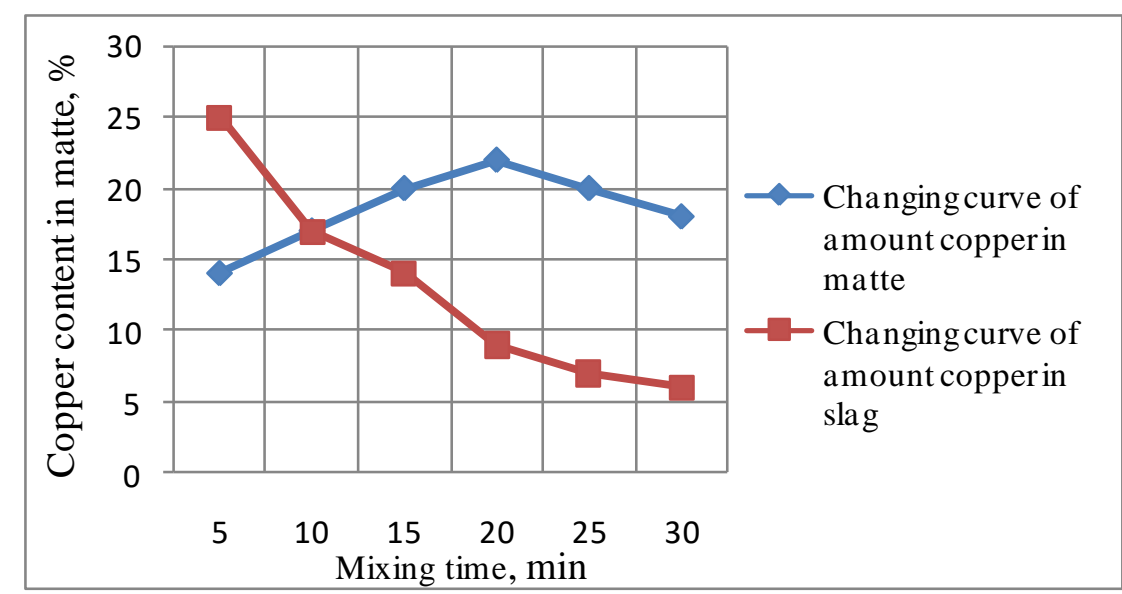

Fig. 4. The effect of argon mixing time on the matte copper content (1) and the residual copper content in the slag (2)

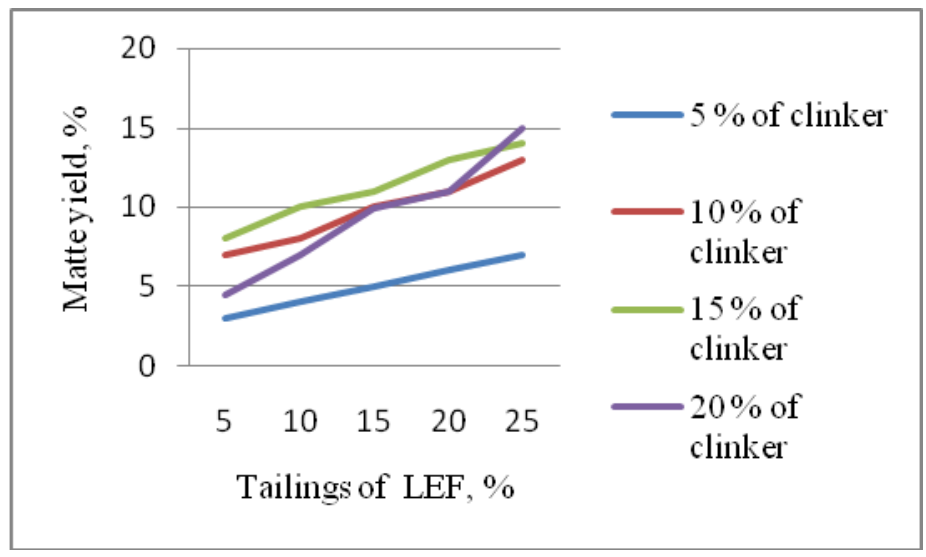

Fig. 5. The dependence of the matte yield on the consumption of tailings of LEF when the slag is depleted in various amounts of clinker, $\%$ of the weight of slag: $1-5 \%$ of clinker; $2-10 \%$ clinker; $3-15 \%$ clinker; $4-20 \%$ clinker 


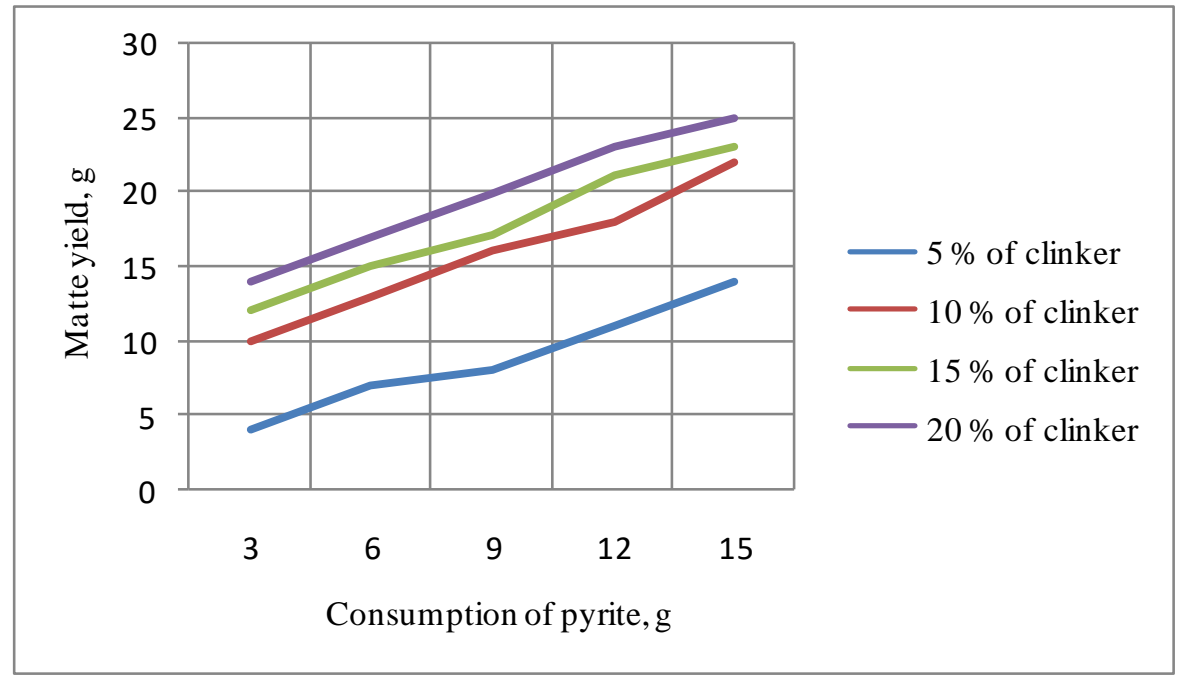

Fig. 6. Dependence of the matte yield (g) on the consumption of pyrite (FeS2) (g) during slag depletion with different amounts of clinker, $\%$ of the slag weight: $1-5 \%$ of clinker; $2-10 \%$ of clinker; $3-15 \%$ of clinker; $4-20 \%$ of clinker

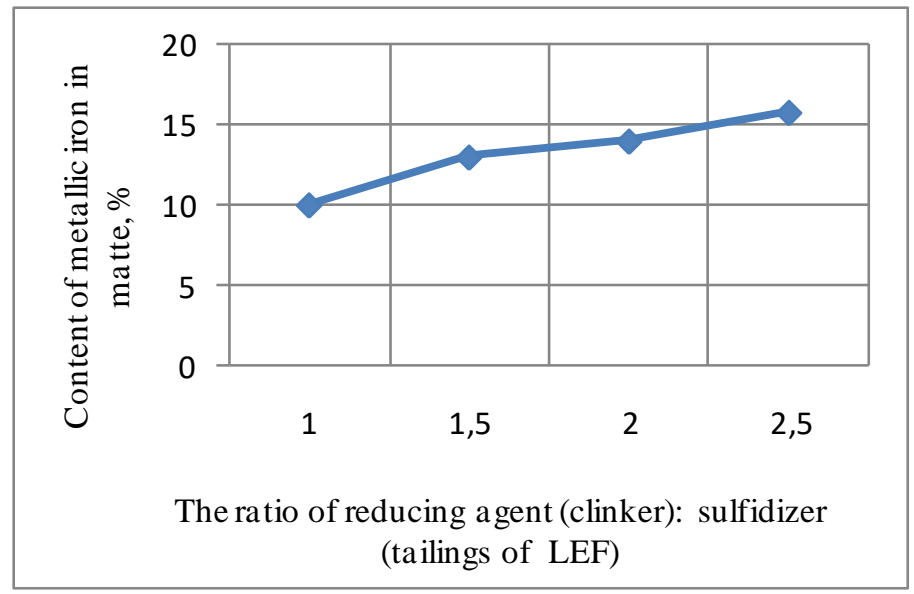

Fig. 7. Dependence of the content of metallic iron in matte on the ratio of reducing agent (clinker): sulfidizer (tailings of LEF)

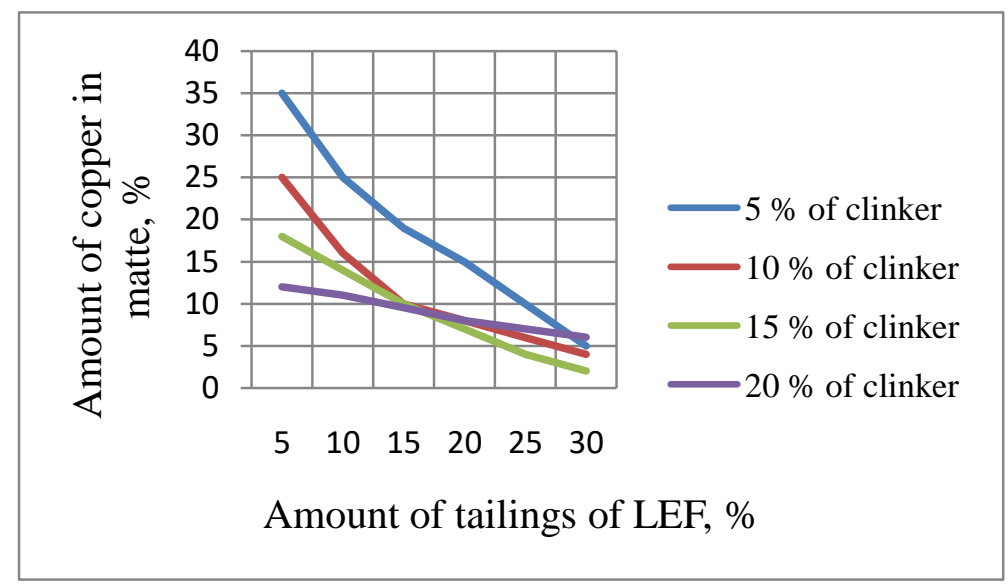

Fig. 8. Effect of tailings of LEF and clinker (\% of slag weight) on the matte copper content 


\section{CONCLUSION}

The pyrometallurgical copper production is characterized by a high yield of clack in relation to the lost metal. Sometimes, when melting the amount of slag, tens of times the yield of valuable industrial products in which the metal is concentrated. Moreover, although the copper content in the slag is relatively small $(0.50-3.50 \%)$, the total losses are an impressive figure. These figures clearly illustrate the significance of the slag processing problem.

If we compare with the copper content in the initial ore, for example, in the ores of the Kalmakir deposit of the Almalyk mining and smelting combine, the copper content does not exceed $0.35-0.42 \%$ with a tendency to its further decrease.

Loss of copper with slags is influenced by many reasons: first of all, precipitation of charge dust on the bath surface, increase in slag viscosity, high magnetite content in melts and oxygen in the gas atmosphere of the furnace, metal dissolution, etc.

As a result of research and development, it was found that the success of the depletion process is largely determined by the solutions to the following problems:

- reduction of magnetite slag to $\mathrm{FeO}$;

- sulfidation of oxidized copper compounds and their transfer to the matte phase;

- adjustment of the slag composition and work on the optimal content of such components as: $\mathrm{SiO}_{2}, \mathrm{CaO}, \mathrm{FeO}, \mathrm{Fe}_{2} \mathrm{O}_{3}$, etc. - bubbling the melt with gases in order to create conditions for the coalescence of small drops of matte;

- the transfer of small drops of matte into the bottom phase by mixing with matte;

The binding of sulfur to the condensed phase, which will simultaneously reduce desulfurization to an acceptable level and transfer it to matte.

To solve the above problem, the authors developed the concept of the lean process, the main provisions of which were as follows:

- reduction-sulfidizing compositions should be composed only of local, not expensive, deficient and unclaimed secondary resources and waste from industrial enterprises;

- the technology should ensure the absence of environmental pollution by smelting products and not go beyond the existing standards;

- the technology should have prospects for a further transition to waste-free;

- the implementation of the technology should be carried out on the basis of existing equipment and technological regulations in the absence or insignificant costs of reconstruction;

- the technical level of technology must comply with the best international standards, taking into account the application to the real conditions of the AMMC;

- in terms of the implementation of this concept, the clinker of the zinc plant was selected as a reducing agent, containing, in addition to the reducing agent, a significant amount of valuable components, including chemically active substances. As the materials - sulfidizers, the tailings of the AMMC copper processing plant, as well as phosphogypsum of the Almalyk chemical plant, as well as gypsum from neutralizing the industrial waste of the smelter were selected.

Processing the above materials in a charge of lean melting will allow the Almalyk mining and smelting complex to expand the raw material base of metal production, improve the environmental situation around enterprises, solve the problem of processing converter slag and get an additional large amount of copper, gold, silver and other metals.

\section{REFERENCES}

1. Rakhimov V.R., Alimkhodjaev S.R., Saidakhmedov H.S. Raw materials for the mining industry of Uzbekistan. "Mountain Journal" 2001. №8. P. 3-5.

2. Shayakubov T.Sh. Mineral resources base of the Republic of Uzbekistan and problems of its development "Geology and mineral resources" 1998, No. 1. P. 3-8.

3. Sanakulov K.S. Scientific and technical basis for the processing of waste from mining and metallurgical industries. Tashkent. 2009 Fan. $405 \mathrm{p}$.

4. Fomenko A.I. engineering ecology: Ecological safety of metallurgical complex enterprises. "Engineering ecology". No. 6. 2001. P. 46-54.

5. Lingevsky B.V. The technique of metallurgical experiment. M. Metallurgy. 2016. -344 p.

6. Yusfin Yu.S., Yusuphodzhaev A.A., Application of physical methods to study the processes of heating and reduction of metallurgical raw materials. In Sat MISiS Proceedings "Preparation of metallurgical raw materials for the keyboard" No. 50, Moscow: Metallurgy. 1969. P 71-79.

7. Yusfin Yu.S., Lizunov G.I., Yusuphodzhaev A.A. Method for express control of metallic iron content. Lime universities. "Ferrous metallurgy" 1985. No. 11. P. 71-79.

8. Yusuphodzhaev A.A. Development of a rational technology for the extraction of copper from slag of copper production. The dissertation for the scientific degree of technical sciences. Tashkent. Institute of General and Inorganic Chemistry, Academy of Sciences of Uzbekistan 2002. - $266 \mathrm{p}$

9. Sanakulov KS, Khasanov AS, Processing of slag from copper production. Tashkent: Fan. 2016. - 256 p.

10. Abdurashid Hasanov, Quvondiq Sanaqulov, Anvar Yusupxodjayev. Rangli metallar metallurgiyasi. Toshkent. O'zbekiston Respublikasi Fanlar akademiyasi: "Fan" nashriyoti, 2015. - 287 p.

11. S. T. Matkarimov, S. Q. U. Nosirkhudjayev, Q. T. Ochildiyev, O. U. U. Nuraliyev, and B. R. Karimdjonov, "Technological processes of receiving metals in the conditions of moderate temperatures, ' Int. J. Innov. Technol. Explor. Eng., vol. 8, no. 12, pp. 1826-1828, Oct. 2019.

12. C. Twigge-Molecey T. Price. Materials Handling in Pyrometallurgy: 1st Edition. Ontario, Pergamon, August 26-30, 2014. - 860 p.

13. Brandt D. Metallurgy Fundamentals: Ferrous and Nonferrous. Goodheart-Willcox Co; 5th edition. 2005. - $301 \mathrm{p}$

14. A.A. Yusupkhodjayev, Sh.T. Khojiyev. Methods of decreasing of Copper loss with Slag in Smelting Processes // International Academy Journal Web of Scholar. Kiev, March 2017, No. 2 (11), Vol. 1, PP. 5 8 .

15. Jang Hyun Sung. Heat Treatment Of Materials. Trans Tech Pubn. 2006-11-15. - 548 p.

16. Markus Reuter, Christian Hudson, Antoinette van Schaik, Kari Heiskanen, Christina Meskers, Christian Hagelüken. Metal Recycling: Opportunities, Limits, Infrastructure, A Report of the Working Group on the Global Metal Flows to the International Resource Panel. United Nations Environment Programme, 2013. - 320 p.

17. A.A. Yusupkhodjaev, Sh.T. Khojiev, S.Sh. Ergashev. Resource-saving technologies in copper metallurgy // Collection of articles by winners of the IXth International scientific-practical conference "World Science: Problems and Innovations", held on April 30, 2017 in Penza. // ICSN "Science and Enlightenment”, Penza, 2017, Part 1, No. 176. P. $157-160$.

18. A.A. Yusuphodzhaev, S.B. Mirzajonova, Sh.T. Khozhiev. Improving the Complexity of the Use of Raw Materials in the Processing of Sulfide Copper Concentrates // Proceedings of the III International Scientific and Practical Conference "Scientific and Practical Results in 2016. Prospects for their Development" (December 27 - 28, 2016, Abu-Dhabi, UAE). Ajman, 2017, No. 1 (17), Vol. 1, c. 45 - 48.

19. Vanyukov AV, Zaitsev V.Ya., Slags and mattes of non-ferrous metallurgy. M. Metallurgy 1969. - 389 p.

20. Shmopin Yu.V. Pyrometallurgical impoverishment of slag non-ferrous metallurgy. M. Metallurgy. 1981. -244 p. 
21. S. T. Matkarimov, B. T. Berdiyarov, and A. A. Yusupkhodjayev, "Technological parameters of the process of producing metallized iron concentrates from poor raw material,” Int. J. Innov. Technol. Explor. Eng., vol. 8, no. 11, 2019.

22. Kurkchi U.M., Yusuphodzhaev A.A., Method for processing metal copper-containing materials A.S. USSR No. 1013502. Issued 12.21.1982

23. Khojiev Sh.T., Irsaliyeva D.B., Muhammadiev Sh.A., Ergasheva M.S. Method for recycling of converter slags into the metallurgical ladle // Современная наука: Актуальные вопросы, достижения и инновации: сборник статей VI Международной научно-практической конференции. - Penza: МЦНС "Наука и Просвещение”. - 2019. Р. 56 - 58.

24. Yusuphodzhaev A.A., Bystrov V.P., Khasanov A.S. Depletion of converter slag from copper smelting by reduction-sulfidizing components. Proceedings of the universities of the USSR. Non-ferrous metallurgy. 1988. No. 6. S. 55-56.

25. Leonard S. Austin. The metallurgy of the common metals, gold, silver, iron, copper, lead and zinc. 2012

26. Arthur H. Hiorns. Principles of extraction metallurgy. 2012.

27. Chen M., Zhao B. Viscosity Measurements of $\mathrm{SiO}_{2}-$ "FeO" $-\mathrm{CaO}$ System in Equilibrium with Metallic Fe // Metallurgical and Materials Transactions: B. 2015. Vol. 46, Iss. 2. P. 577-584.

28. Yusupkhodjaev A.A., Nosirkhodjaev S.Q., Matkarimov S.T. Physical and Chemical Transformations of components of Fusion Mixture at their heating in Metallurgical Furnace // International Journal of Advanced Research in Science, Engineering and Technology. Vol. 6 , Issue 1, January 2019. P. 7945-7952.

29. H.U. Bozgstedt. Material behavior and physical chemistry in liquid metal systems. Sep. 12. 2014.

30. A.A. Yusupkhodjayev, Sh.T. Khojiev, S.B. Mirzajanova. Usage of reducing-sulfidizing agents in copper-bearing slags depletion // Collection of articles of the International scientific-practical conference "Management of socio-economic systems: theory, methodology, practice", held on June 15, 2017 in Penza. // ICSN "Science and Enlightenment", Penza, 2017, Part 1, No. 190. P. 19-21.

31. A.A. Yusupkhodjayev, Sh.T. Khojiev, J. Usarov. Reason of copper loss with slag // Collection of articles of the International scientific-practical conference "Management of socio-economic systems: theory, methodology, practice", held on June 15, 2017 in Penza. // ICSN “Science and Education”, Penza, 2017, Part 1, No. 190. P. $22-23$.

32. Yusupkhodjaev A.A., Khojiev Sh.T., Valiev X.R., Saidova M.S., Omonkhonov O.X. Application of Physical and Chemical Methods for Processing Slags of Copper Production // International Journal of Advanced Research in Science, Engineering and Technology. Vol. 6 , Issue 1, January 2019. pp. 7957 - 7963.

33. Khojiev Sh.T. Pyrometallurgical Processing of Copper Slags into the Metallurgical Ladle // International Journal of Advanced Research in Science, Engineering and Technology. Vol. 6, Issue 2, February 2019. pp. $8094-8099$

34. Davenport W. G. L., King M., Schlesinger M., Biswas A. K. Extractive Metallurgy of Copper. - $4^{\text {th }}$ edition. - Oxford: Pergamon, 2002. P 155-171.

35. Yusuphodzhaev A.A., Khasanov A.S., Bystrov V.T. and others. The method of depletion of slag. A.S. USSR No. 1671716 dated 04/22/1991.

36. Yusupkhodjaev A.A., Khojiev Sh.T., Suyunova M.N., Babaev B.S Mechanical and physico-chemical copper losses in slags // Modern Technologies: Actual Issues, Achievements and Innovations: Collection of Articles of the XXVII International Scientific and Practical Conference. - Penza: ICSN "Science and Enlightenment". 2019.S. 68 - 70.

37. Khojiev Sh. T., Safarov A. X., Mashokirov A. A., Imomberdiyev S. F., Khusanov S. U., Umarov B. O. New method for recycling of copper melting slags// Международный научный журнал "Молодой Учёный”, № 18 (256), часть II. -Казань: издательства «Молодой ученый», 2019. C. 133 - 135.Sanakulov K.S., Khasanov A.R. Processing slag of copper production. Tashkent: "Fan", 2007. -260 p.

38. Mechev V.V., Bystrov V.P., Tarasov A.V. Autogenous processes in non-ferrous metallurgy. - Moscow: "Metallurgy", 2011. - 413 p.

39. Gorby G. Anderson and Robert G. Dunne. Mineral processing and extractive Metallurgy 100 Years of Innovation. Feb. 18. 2014. -286 p

40. Leonard S. Austin. The Metallurgy of the Common Metals: Gold, Silver, Iron, Copper, Lead and Zinc. 2012. -296 p.

41. Shamsuld M. Phisical Chemistry of Metallurgical Processes. Willy -TMS. 1 edition (February 29, 2016). P. 364
42. Kupryakov Yu.P., Chakhotin V.S., Prikhodko Yu.I. and other "Non-ferrous metallurgy" (Bull. Institute "Colormetinformation"), 2011, No. 18, pp. 35-40.

43. Avetisyan H.K. Blister copper metallurgy. -Moscow: Metallurgizdat, 2014, 47 p.

44. Yusuphodzhaev A.A. Development of a rational technology for the extraction of copper from copper slag. The dissertation for the degree of Doctor of Technical Sciences. Tashkent, 2002 . -266 p.

45. Tarasov A.V. New in copper metallurgy // Non-ferrous metals, 2002 No. 2. pp. $38-45$

46. A.K. Biswas, W.G. Davenport. Extractive Metallurgy of Copper Pergamon, 2014, P. 489.

47. Lynch D. C., Akagi S., Davenport W. G. Thermochemical Nature of Minor Elements in Copper Smelting Mattes. Metallurgica Transactions. 2009. Vol. 22. pp. 677-688.

48. Kurbatsky M.N., Gibadullin M.F. Processing and use of metallurgical OJSC MMK. "Metallurgist". No. 1. 2002. pp. 47-48.

49. A.A. Yusupkhodjayev, Sh.T. Khojiyev. Methods of decreasing of Copper loss with Slag in Smelting Processes // International Academy Journal Web of Scholar. Kiev, March 2017, No. 2 (11), Vol. 1, pp. 5 8 .

50. A.A. Yusupkhodjayev, Sh.T. Khojiev, S.B. Mirzajanova. Usage of reducing-sulfidizing agents in copper-bearing slags depletion // Collection of articles of the International scientific-practical conference "Management of socio-economic systems: theory, methodology, practice", held on June 15, 2017 in Penza. // ICSN "Science and Enlightenment", Penza, 2017, Part 1, No. 190. pp 19-21.

51. Yusupkhodjaev A.A., Khojiev Sh.T., Valiev X.R., Saidova M.S. Omonkhonov O.X. Application of Physical and Chemical Methods for Processing Slags of Copper Production // International Journal of Advanced Research in Science, Engineering and Technology. Vol. 6 Issue 1, January 2019. pp. 7957 - 7963.

52. Khojiev Sh.T. Pyrometallurgical Processing of Copper Slags into the Metallurgical Ladle // International Journal of Advanced Research in Science, Engineering and Technology. Vol. 6, Issue 2, February 2019 pp. 8094 - 8099

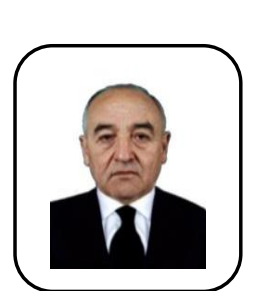

\section{AUTHORS PROFILE}

Yusupkhodjaev Anvar Abdullaevich received his Doctoral (Dr.Sci.) degree in the Metallurgy of noble, rare, non-ferrous Metals program in the department of "Metallurgy" of Tashkent State Technical University, in 2005. At the moment he is working as professor of this department. He is one of the Chief Metallurgists of Uzbekistan. His research works about development of recycling of metallurgical wastes.

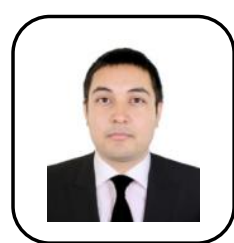

Khojiev Shokhrukh Toshpo'latovich received his Master's degree in the department of "Metallurgy" of Tashkent State Technical University in the republic of Uzbekistan. At the moment he is working as senior teacher and researcher of this department. His research works about development of recycling of copper slags with local reducing agents and improvement of integrated technology of recycling metallurgical wastes together.

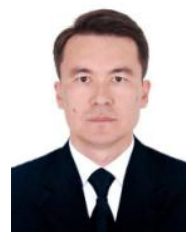

Berdiyarov Bakhriddin Tilovkabulovich, Head of Department of Metallurgy, Tashkent state technical university, $\mathrm{PhD}$

University Street 2, Tashkent, Uzbekistan, 100095

E-mail: mr.berdiyarov@gmail.com

Phone number: 99897 411-00-31

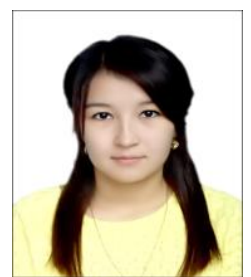

Yavkochiva Dilfuza Odilovna, Assistant of Tashkent state technical university Termez Branch. Islam Karimov Street 288/A, Termez, Uzbekistan, 132000

E-mail: yavkochiva.d@gmail.com Phone number: 99897 594-00-33 
Technology of Processing Slags of Copper Production using Local Secondary Technogenic Formations

Ismailov Jonibek Bahadirovich, Assistant of

Metallurgy, Tashkent state technical university,

University Street 2, Tashkent, Uzbekistan, 100095

E-mail: jonibek.ismailov@tdtu.uzm

Phone number: 99893602 -78-76 